\section{A tale of two seminars}

\section{London}

SENIOR academics from across the United Kingdom were left dissatisfied after a meeting last Friday at the Natural History Museum in London that had been called to discuss the museum's future as a scientific research centre. The scientists had been invited by the museum's director, Neil Chalmers, so that he could answer criticism of his 1990-95 corporate plan, but after the meeting ended many complained that they had received no new information. The plan makes provision for far-reaching changes in the way research is organized at the museum, which will include the loss of one in six research posts.

The cuts are planned because nearly all the museum's government grant - more than £16 million - is consumed by salaries. "However much it hurts, we must lose posts", Chalmers reiterated at the meeting. In the plan, Chalmers has asked the Office of Arts and Libraries (OAL), the museum's main source of funds, to make up a shortfall estimated at $£ 4.4$ million over the next five years "so we can plan sensibly - we need that extra money just to stand still. We do have a real problem even if we do get this $£ 4.4$ million. If we don't, we face a devastating problem." Associate director John Peake presented the first stage of the museum's science strategy, which as yet goes little further than the broad statements outlined in the corporate plan.

The official presentation was preceded by a branch meeting of the Institution of

COMPUTER NETWORKS

\section{NSFNET hits its stride}

\section{Washington}

MAJOR portions of NSFNET, the massive scientific computing network that links more than 1,500 universities, research centres and supercomputer facilities, are to begin operation at 28 times their previous speed by the end of the year, the National Science Foundation (NSF) announced last week. With the upgrade, NSFNET will become the world's fastest computer network.

The $\$ 7.9$ million effort will raise the data-transfer rate for eight major US research centres from ' $\mathrm{T} 1$ ' to 'T3' speed an increase from 1.5 to 45 million bits per second. Two new T3 nodes, which connect NSFNET to mid-level regional networks, will be added at the Massachusetts Institute of Technology and the Argonne National Laboratory. NSFNET established a T1level connection to the European Centre for Particle Physics (CERN) several months ago (see Nature 344, 279; 22 March 1990).

G. Christopher Anderson
Professionals, Managers and Specialists (IPMS), the scientists' trades union. IPMS representatives called on the management to treat staff and their research with respect by abandoning the corporate plan, and giving substance to the advertised desire of the Prime Minister, Mrs Margaret Thatcher, to establish a Europe-wide systematic data-base in which the NHM could use its greatest strength - taxonomic research - to the full. This concern was voiced in the House of Commons by Mr Tam Dalyell, Labour MP for Linlithgow, Scotland. "It is a feature of the plan that the cuts do not relate to stated aims, even when the aims are the Prime Minister's", he said (Hansard, 11 June $1990 ;$ p.80).

At the official seminar, Chalmers said that NHM had taken the lead in coordinating museum research across Europe to avoid unnecessary duplication of effort

The union meeting, also held in the museum, went ahead as planned despite, the IPMS alleges, efforts by the management to postpone it. Palaeontologist $\mathrm{Dr}$ Richard Jefferies, secretary of the IPMS science defence committee convened to draw attention to the cuts, addressed the meeting despite earlier threats of disciplinary action were he to do so. Jefferies likened the progressive attrition of funds at the NHM to the shrinkage of planarian flatworms during starvation: organ systems are lost in sequence, but the last to go is the nervous system. "That's the management", he said.

In what the IPMS criticize as an increasingly secretive management style, the provisions of 1990 corporate plan - unlike every other corporate plan since 1986 - were not discussed with staff before its completion. The trustees delayed approval of the plan from February until April, but its contents were effectively secret until 23 April, when staff were presented with what they see as a fait accompli.

Chalmers also noted the success of a new development fund (see Nature 241, $477 ; 1989$ ) in raising money to put on new permanent exhibitions. These new displays will revamp a museum in which more than half the exhibition space is empty or has not changed for more than 15 years. But at the IPMS meeting, designer Ann Hollifield pointed out that to do this, the museum plans to bring in outside design contractors at the expense of the inhouse team. Good exhibitions stem from a "marriage" between design and science, claims Hollifield, who is to be made redundant this autumn. The policy rethink is "throwing away years of investment in the in-house design team" and replacing the "marriage" with "a series of one-night stands".
Henry Gee

\section{Environmental aid "a priority"}

\section{London}

RESPONDing to frank descriptions from Eastern European environment ministers of the pollution problems they face, European Communities (EC) environment ministers agreed in Dublin last week that environmental protection should be given priority in the EC aid package for Eastern Europe. Non-EC European countries, including the Soviet Union, will also be free to join the EC's planned European Environment Agency - an environmental datacollection and monitoring service to be established later this year. The Dublin meeting was the first ever between EC and East European ministers.

So far, only Poland and Hungary have recevied EC aid, gaining between them 300 million ECU $(1 \mathrm{ECU}=£ 0.70)$ with 49 million ECU earmarked for environmental protection. The Dublin agreement should mean that pollution control schemes will be emphasized in the additional 200 million ECU package planned for Bulgaria, Czechoslovakia, East Germany, Romania and Yugoslavia.

Polish environment minister Bronislaw Kaminski said that economic reforms are central to the fight against pollution. His government hopes that the removal of government subsidies on coal will reduce the country's profligate energy use.

Peter Aldhous EDUCATION

\section{United States science in decline}

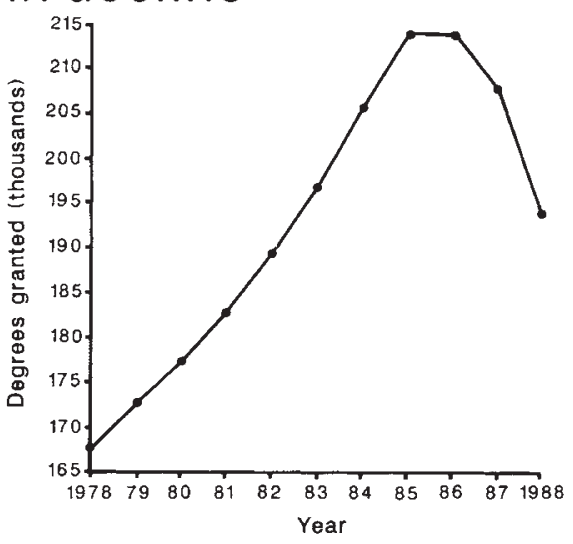

THE number of US students receiving undergraduate degrees in the natural sciences dropped nearly 10 per cent over two years, according to National Science Foundation statistics. Defined as the fields of engineering, physics, chemistry, mathematics, computer science, biology and environmental sciences, the group suffered a loss of more than 20,000 degrees between the years 1986 and 1988. During that period, the overall number of degrees granted to US students in all fields rose by nearly 6,000 , to an all-time high of 1,006,033. G. Christopher Anderson 